\title{
RELATIONSHIP BETWEEN THE MOTHER'S CHARACTERISTICS AND HER PERFORMANCE OF TREATMENT PROGRAMMES FOR HER HANDICAPPED INFANT
}

\author{
T. H. A. KOLOBE, M.Sc., Nat. Dip. Physio.*
}

\section{SUMMARY}

\begin{abstract}
Maternal characteristics of 25 mothers measured by questionnaire scales and their performance of their infants' physiotherapy treatment activities were correlated to determine the nature of this relationship. The results showed that mothers with positive attitudes, internal locus of control and middle socioeconomic status tend to perform their infants' treatment activities better than do mothers with negative attitudes, external locus of control and low socioeconomic status.
\end{abstract}

The results also add support to the idea that if professionals involved in early intervention programmes are to help the child in a meaningful and effective way, they should be aware not only of the child's developmental status, but also of the mother's mental or emotional status and be prepared to provide help in the lacking areas.

The findings also indicate that the effectiveness of early intervention programmes will not only depend on the type of therapeutic techniques utilized but on the mother. The mother's attitude was the main contributor to how well she performed her infant's treatment activities.

\section{OPSOMMING}

25 Moeders en hul babas is getoets om die karaktertrekke en verhoudings tot hul babas vas te stel. Die moeders is getoets deur middel van 'n vraelys en die kinders se prestasies en moederlike verhoudings is vasgestel gedurende fisioterapie behandeling en aktiwiteite. Die uitslag het getoon dat moeders en kinders uit die middel sosioekonomiese klas met 'n positiewe houding en begrip baie beter vaar as die moeders en kinders uit die laer sosio-ekonomiese klasse met negatiewe houdings en begrippe.

Verder ondersteuning is verleen aan die idee dat vir professionele hulp en vroeë betrokkenheid deur middel van programme van waarde vir die moeders en kinders te wees, moet die beroepsmens bewus wees van nie net die kind se ontwikkeling nie, maar ook die moeder se emosionele en verstandelike toestand en bereid wees om hulp in hierdie areas te verleen.

Die bevindings toon ook baie duidelik dat die sukses van hierdie vroee betrokkenheid nie alleenlik van die terapeutiese tegnieke wat die moeder sal gebruik afhang nie, maar van veel groter belang is die moeder se positiewe houding en begrip.

\section{NTRODUCTION}

Early intervention to enhance normal development in infants considered at risk for developmental disorders or infants with diagnosed neurodevelopmental disorders is increasingly utilized by physiotherapists. An assumption of early intervention is that it leads to a better developmental outcome.

Early intervention programmes are geared toward the infant and the preschool child, with the primary caregiver as the infant's therapist, under the guidance and supervision of the professional. The emphasis for management of the infant therefore shifts from the medical staff to the family because the child spends most of this period at home. An extensive review of studies concerned with early intervention shows that two factors are crucial to the success of early intervention:-

1. Parental involvement or the primary caregiver's involvement (Shearer 1976; Bronfenbrenner 1975)

${ }^{*}$ Lecturer, Physiotherapy Department, Medical University of Southern Africa

2. The quality of mother-child interaction (Bronfenbrenner 1975).

The fact that the quality of mother-child interaction between parents with their handicapped infants is different from that observed in parents with their non-handicapped infants, has been repeatedly observed and documented. Parenting a handicapped child has been observed to impose certain kinds of stress on parent's coping styles, responses and behaviours (Kogan el al. 1976; Mackeith 1973). These responses have been isolated as antecedents of later infant development by psychologists and educators whose aim was to improve cognitive and social functioning of the infant as well as improve the quality of mother-child interaction (Parke 1977). In short, they investigated the effects of maternal characteristics on their intervention programmes.

Similar research is practically non-existent in Physiotherapy. Very little is known about how social, attitudinal, cmotional characteristics and beliefs of parents of handicapped children contribute to the effectiveness of parent education, nor how these characteristics can influence or be influenced by physiotherapy intervention programmes. For physiotherapists to assume that the general conclusions of 
investigators who examined intellectual and social development could be applied to perceptual and motor development would be a fallacy. Furthermore the need exists to understand the influence of these characteristics before plunging into the pursuit of data that simply would reinforce the sense of confusion already present in the literature concerning the effectiveness of early treatment of children with central nervous system (CNS) disorders.

In summary, early intervention is dependent upon the mother for success. Also, early intervention is dependent on the quality of mother-child interaction which in turn is dependent upon certain maternal behaviours and characteristics. Interaction of maternal characteristics and intervention procedures should therefore greatly influence the outcome of infant development (and indirectly - the outcome of physiotherapy intervention).

The purpose of the study was to investigate the nature (if any) of the relationship that exists between maternal characteristics and her ability to follow through with physiotherapy intervention activities for her handicapped infant. Maternal Perceptions, Maternal Attitudes, Maternal Locus of Control (LOC), Maternal Socioeconomic Status (SES) and Level of Education were isolated and studied because they have been shown to be major contributors to mother-child interaction and coping bahviours. A few operational definitions and related studies should clarify these variables:

\section{MATERNAL PERCEPTION}

Maternal perception as used in the present study refers to the mother's interpretation and evaluation of observed infant behaviours and temperament. According to Broussard and Hartner (1971) the manner in which the parent perceives her infant has an impact on the nature of infant behaviours to which she will respond. Perception tends to reflect the mother's state of mind according to Carey and McDevitt (1979)

\section{MATERNAL CHILDREARING ATTITUDES}

The word "attitude" encompasses a variety of behaviours which explains a variety of conclusions derived from many studies on parental attitudes. The subject of maternal attitudes toward childrearing having an impact on child development is by now a familiar story (Pearson 1931; Schaefer and Bayley 1964). Relevant to the present study is a fairly general agreement that mothers of handicapped children are susceptible to certain specific attitudes particularly in the early years following the birth of the baby (Greenberg 1971, Voysey 1975).

\section{MATERNAL LOCUS OF CONTROL (LOC)}

LOC is a construct that refers to people's consistency to ascribe the results of their behaviour to either external sources such as fate or internal sources such as beliefs that when things happen, "it is your doing". Rotter (1954) writing from the perspective of social learning theory, labelled the sense of having an influence on the events in one's life as indicating an internal LOC. He described the converse, an external LOC as the feeling that events are not contingent upon one's own actions but are the consequences of the powers of others.

\section{MATERNAL SES AND LEVEL OF EDUCATION}

These are self explanatory

It was hypothesized that:

1. The mother's perception of her infant's temperament will be positively related to how well she performs her infant's physiotherapy activities.
2. Mothers who score high in negative childrearing and educational attitudes will exhibit greater difficulty in performing their infants' treatment activities than mothers who score high on positive attitudes.

3. Mothers with internal LOC will demonstrate better ability to follow through with their infants' physiotherapy activities than mother's with external LOC.

4. No difference in performance will be exhibited by mothers with high SES and low SES.

5. Mothers with higher levels of education will demonstrate better performance than mothers with lower education.

Maternal ability to follow through or Maternal Performance as used in this study refers to the degree of accuracy and independence with which the mother can perform activities she had been taught over a period of time. This is assuming the mother has been practising the activity with her child.

\section{METHOD}

\section{SUBJECTS}

Twenty-five mothers whose infants met the following criteria participated in the study:

1. Had sensorimotor problems with motor developmental delays with psychomotor Developmental Index on the motor scale of the Bayley Scales of Infant Development (1969) between -1 and -3 standard deviations from the scale's mean of 100 ;

2. Age 36 months or younger;

3. Normal sight;

4. Currently receiving physiotherapy on a regular basis (at least twice a month);

5. Mothers who were their primary caretakers and natural mothers.

15 infants were females while 10 were males.

\section{MATERIALS}

Three questionnaires, the Infant Temperament Questionnaire (ITQ) (Carey and McDevitt 1978) and the Toddler Temperament Scale (TTS) (Fullard er al. 1979), the modified Childrearing and Educational Research Instrument (CERI) (Schafer 1981) and the Rotter Internal-External Locus of Control Scale (Rotter 1966), were utilized to measure maternal perceptions of her infant's temperament, maternal attitudes and maternal LOC respectively. The Hollingshead Index of Social Class (Hollingshead 1958) was used to determine the SES and the Parent Performance Scale (Wilson 1976) was utilized to rate the mother's ability to carry out the treatment activities.

\section{DESIGN (Refer Figure 1)}

The experiment was run in three phases over a period of at least four weeks for each mother-child pair. All but six pairs were seen in their homes.

\section{PROCEDURE}

\section{Phase 1}

The mothers were given the questionnaires by the therapist or the parent trainer who usually worked with the motherinfant pair.

Phase 2

Physiotherapists who usually worked with the pairs participated in the teaching and testing sessions. The method of parent teaching utilized was similar to that used in the Portage Project described by Shearer (1976). Each therapist, prior to the teaching session, was given a list of activities 
PHASE 1

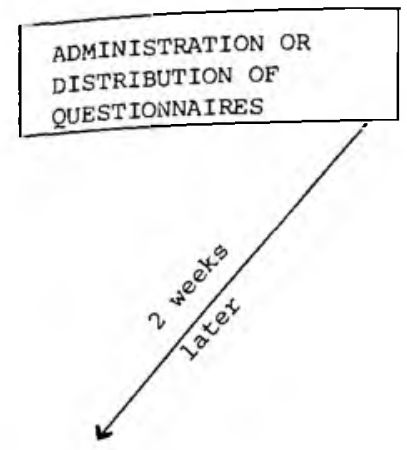

1. ITQ or TTS

2. CERI

3. Rotter Interna1-External LOC Scale

PHASE 3

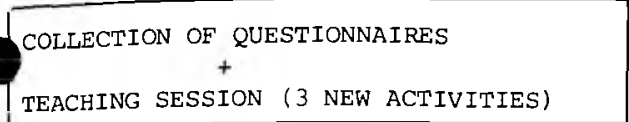

\begin{tabular}{ll|l|}
\hline LATER WEEKS & $\begin{array}{l}\text { PERFORMANCE EVALUATION } \\
\text { OR TESTING SESSION } \\
\text { Gathering of additional } \\
\text { information of the } \\
\text { mother (SES, level of } \\
\text { education, etc.) }\end{array}$ \\
\hline
\end{tabular}

Parent Performance Rating Scale

Additional Information Form

Fig. 1. The Design of the Study.

from the Kentucky Physical Therapy Program (Jaeger 1980) from which to choose at least three appropriate activities which met specified criteria.

This investigator observed the teaching session. The mother's final performance (considered satisfactory by the physiotherapist, was then rated according to the Parent Performance Rating Scale criteria (Wilson 1974).

The mother was also given copies of the Kentucky programme for consultation.

\section{Phase 3}

The therapists received instruction and were given a podified Vulpe performance analysis scale test prior to the esting session. The testing session consisted of the rating of the mother while she performed the activities taught in phase 2.

Following phase 3 the investigator gathered data on the other variables to be analyzed. This information was collected last in order to minimize observer or rater bias on the part of the investigator.

\section{RESULTS}

The average performance of the mothers was 23 with scores ranging from 18 - 28 (Figure 2).

The correlation matrix shows a significant positive relationship between maternal attitudes and performance and a negative significant relationship between maternal locus of control and performance. There is no significant relationship between maternal education and performance (Table 1).

A chi-square run showed a significant relationship between maternal SES and performance and no significant relationship between maternal perceptions and performance. A stepwise multiple regression showed that maternal attitudes was the main contributor to maternal performance. Maternal attitudes, SES and LOC explained $45 \%$ of the variance (Table 2).

\section{DISCUSSION}

The present study demonstrated relationships between some psychological and demographic characteristics of the mother and her performance of physiotherapy intervention

Table 1. Correlation Matrix of Maternal Variables

$\begin{array}{lccc} & \text { Attitudes } & \text { LOC } & \text { Education } \\ \text { LOC } & -0.5457^{* *} & & \\ & p=.002 & & \\ \text { Education } & 0.416^{*} & -0.0834 & \\ & p=0.19 & p=.346 & 0.0324 \\ \text { Performance } & 0.5115^{* *} & -0.5133^{* *} & \mathrm{p}=0.439\end{array}$

${ }^{* *}=$ significant at $\mathrm{P}<.005$.

$*$ = significant at $\mathrm{P}<.05$. 


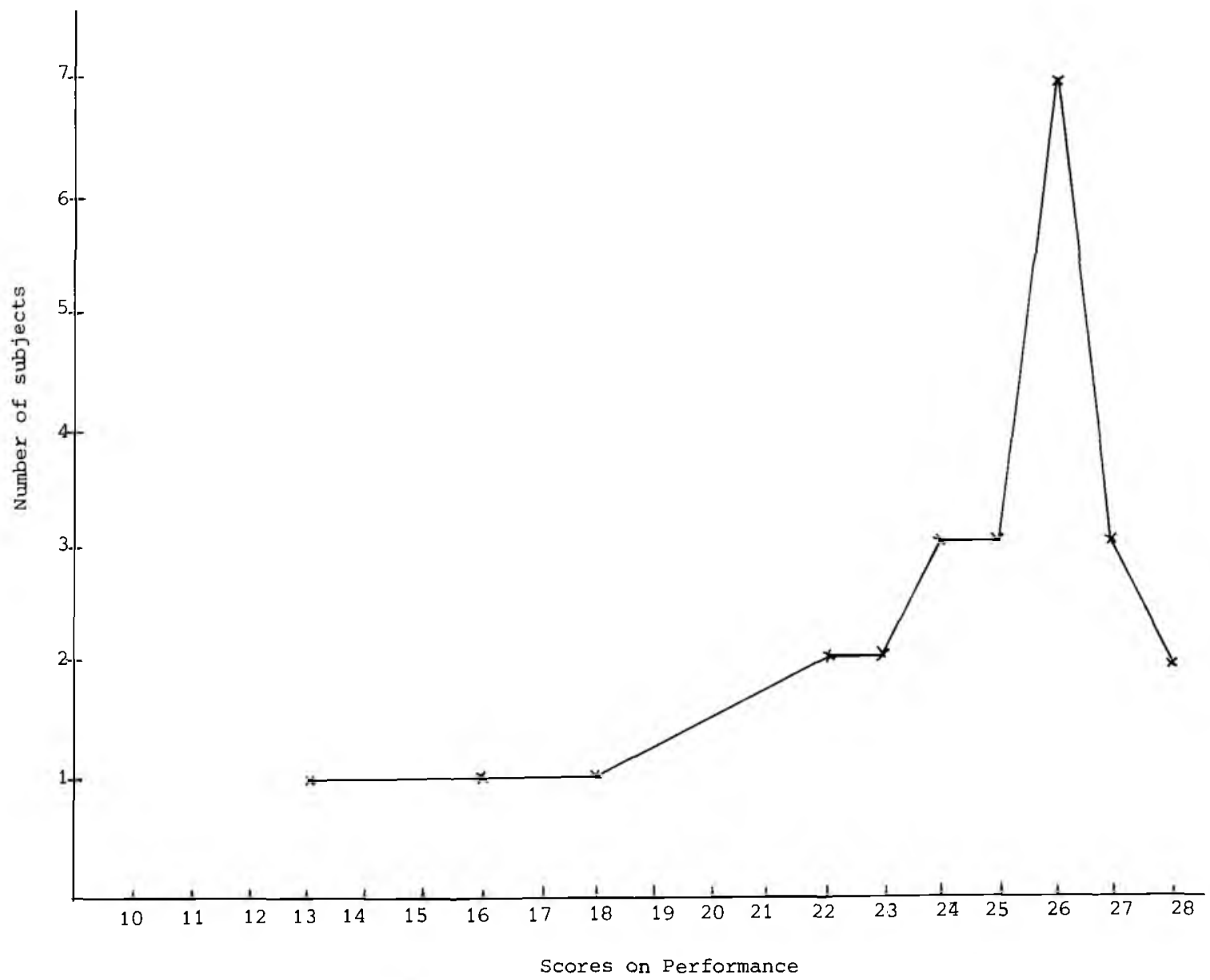

Fig. 2. Performance - Scores and Frequency.

activities with her infant. The findings under each variable studied will be discussed as well as their implications for early intervention programmes in physiotherapy.

\section{MATERNAL PERCEPTIONS}

No significant relationship was found between the mother's perception of her infant's temperament and her ability to perform her child's treatment activities.

Few variables intercorrelated with perceptions which are beyond the scope of this paper.

It should be pointed out though that of the five children perceived as "more difficult than average" by their mothers, only one child's temperament was diagnosed as more difficult than average.

While most parents do not like to rate their infants as difficult, this discrepancy may reflect the mother's coping behaviour problems which could be remedied by appropriate intervention programmes.

\section{MATERNAL ATTITUDES}

Mothers who scored high on positive attitudes tended to score high in their performance of their infants' treatment activities. Attitude was the major contributor to the mother's performance (Table 2).

Theories and observations made by Schaefer (196l) and
Klinger (1975) may explain the results on parental attitudes obtained in this study:

\section{Inappropriate or conflicting interpersonal interaction}

The CERI scale measures specific negative attitudes such) as:

Does the mother expect the child to conform to her expectancies? etc.

A child who does not exhibit responses desired or expected by such a mother during therapy or through therapy will conflict with the expectations of the mother. In addition to that, if the mother is not aware of, or knowledgeable about the limited adaptive capacities of the infant with CNS disorders, she might feel opposed or develop a negative attitude towards the infant. Her enthusiasm towards physiotherapy, as well as the consistency with which she practices the activities, might decrease. This is where the physiotherapist's professional support would be valuable.

2. The "ineffectiveness" of intervention to meet that particular mother's needs and the slow development of the child

Beginning treatment may well facilitate a perceived developmental spurt in skills which the child has not previously been able to demonstrate without help. In Klinger's (1975) formulation, this may constitute a reward that maintains the parent in pursuit of a goal. 
Table 2. MULTIPLE REGRESSION

Variables in the Equation

$\begin{array}{lc}\text { Variable } & B \\ \text { Attitude } & 0.3696380 \\ \text { Education } & -0.315052 \\ \text { SES } & -0.3911584 \\ \text { LOC } & -0.1806355 \\ \text { Constant } & 3.240437\end{array}$
BETA
0.52425
c 30.53192
$-0.46320$
$-0.19366$

\section{Summary Table}

$\begin{array}{lc}\text { Variable } & \text { Mulliple } R \\ \text { Attitude } & 0.50653 \\ \text { Education } & 0.54560 \\ \text { SES } & 0.64817 \\ \text { LOC } & 0.67358\end{array}$
$R$ Square
0.25657
0.29768
0.42013
0.45371

$R S Q$ Change
0.25657
0.04111
0.12245
0.03358

\author{
STD Error $B$ \\ 0.12818 \\ 0.13188 \\ 0.17956 \\ 0.16292
}

$f$.

8.316

5.707

4.766

1.229
The parent may expect to see development continue at the accelerated rate of this initial spurt and may be discouraged if this does not occur. When development does not continue at this higher rate, the results, according to Klinger (1975) may be negative attitudes and disengagement from the goal.

Further exploration by longitudinal studies that focus on the changing attitudes of mothers as physiotherapy intervention continues are necessary. A change from positive to negative during the course of therapy could serve as a warning to the physiotherapist of a potential disruption with interaction between mother and child or therapist, or as an indication for programme re-evaluation.

An interesting observation was made from the findings of mothers with negative attitudes: almost all their infants were less than twelve months of age. Retrospective data analysis indicated that these infants were diagnosed as "high risk infants" or as having "developmental delays". Possibly because these children do not have a definite diagnosis of abnormality, their mothers were uncertain as to how they should relate to them, or how involved they should be in their therapy.

Such uncertainty may result in emotional strains, denials or negative attitudes on the part of the mother and consequently inconsistency in practising therapeutic activities vince she does not know what she is supposed to be treating. If this observation holds, further controlled research is indicated. The questions to address will be:

a. Does delayed diagnosis have an impact on the mother's attitudes and if so, how?

b. Is there a difference in maternal attitudes between mothers of children with known CNS disorders and those that are at risk for developmental delays?

\section{LOCUS OF CONTROL}

Mothers with internal LOC exhibited better performance than mothers with external LOC.

The results support the findings that have shown that the parents' understanding and beliefs in their ability to change their infants' development are critical to the success of intervention. According to Rotter (1966) if one does not perceive one's experiences as the consequences of one's own actions, those experiences are not effective for altering the ways in which one sees things and consequently functions.

These findings should be a warning to those physiotherapists who often get so involved with the child during therapy that they often forget the mother, particularly if the mother appears not to be interested.

Lefcourt (1976) states that external beliefs result in poor coping behaviours.

\section{SOCIOECONOMIC STATUS (SES)}

The results showed that middle SES mothers tended to perform their children's treatment activities better than did low SES mothers. Perhaps the maternal ability to learn and transfer a teaching skill is a critical factor that differentiates the behaviour of middle and low SES mother. This study like the Brophy (1970) study, involved teaching parents how to teach their own children and similar results were observed -Mothers varied according to their SES even with factors such as the complexity of the task controlled.

This is an indication that, since the SES of the mother cannot be influenced or changed, physiotherapists involved in parent education will have to adapt their teaching methods to suit the SES of the mother.

\section{LEVEL OF EDUCATION}

Lack of a significant relationship between the mother's level of education and her performance could be an indication that the mother's level of education is indeed not related to how well and consistently she performs physiotherapy activities. A general view held by researchers in the area of child development is that the more educated the mother is, the better learning opportunities and experiences she will provide her child.

Most of their findings have focussed on cognitive and social development of the child and not the motor aspect of development. Furthermore, the studies often incorporate the level of education into the SES factor. There is thus still a question of whether other environmental factors surrounding the better educated mother, and not the level of education itself, are actually responsible for behaviour differences observed. Either way, these results are a further indication that physiotherapists should not readily apply the findings of studies that investigate cognitive and social development to their situation without conducting studies related to physiotherapy intervention.

The findings on maternal level of education may also support the clinical observations made by therapists that most highly educated mothers are more concerned about their handicapped children having a normal I.Q. than they are about their infants walking. 


\section{RECOMMENDATIONS}

The present study has shown that mothers of handicapped children exhibit variability in their responses to situations, their attitudes and beliefs. This further reinforces the philosophy or practice that each child and each family of a handicapped child is unique and should be treated as such.

At the same time the results indirectly point out the futility of studying the effectiveness of early intervention in research, i.e., comparing the children's developmental gains in treated versus untreated situations without taking into consideration the caretaker's psychological and demographic variables or without clearly understanding the nature of their interaction with intervention procedures.

1. While the physiotherapist is not totally responsible for interpreting subtle or overt maternal behaviours, attitudes and beliefs, he or she should understand the meaning of these attitudes and how they may or may not influence the treatment plans for the child or affect the relationship with the mother. Most parents, as observed by Burden (1980) regarded physiotherapists as a source of their professional support and tended to share their concerns or problems with them. Physiotherapists in early intervention may use the scales to measure these attributes and relate them to the developmental gains or improvements assessed in the children over a period of time.

2. Physiotherapists need to evaluate consistently the mother's ability to carry out every new activity she is taught. The importance of this is three-fold. Firstly, to minimize the mother's feelings of inadequacy and increase her self confidence. Secondly, to increase the likelihood of the mother practising the activities once she knows the physiotherapist will ask her to go over them with her. Thirdly, the physiotherapist is kept keyed in on what she teaches or has taught the parent. This acts as a cont rol on the number of new activities that the therapist introduces with every visit. This way the mother is also not overwhelmed with activities. The latter is a common practice of many physiotherapists and can be very confusing to the mother who is the recipient of all these new ideas.

3. Working with parents is a skill that many physiotherapists are not taught during their professional training. Most physiotherapy educational programmes focus on development of skills in working with the child. The treatment goals are also designed with more focus on the child's development and needs and seldom on the family's needs.

The scales utilized in the present study can be used by physiotherapists to obtain a rough estimation of where the mother is emotionally in relation to her child, and to determine what positive points about her child need to be emphasized.

Therapists should bear in mind that families devote enormous amounts of time and energy to the care and training of their handicapped children often with /itle immediate reward.

4. Large sample or small sample longitudinal studies using perceptions, attitudes and LOC as dependent measures of intervention over time in parent-child intervention programmes, will render more valuable information than will cross-sectional studies. Changing trends in perceptions, attitudes or LOC may be more pertinent to physiotherapy intervention programme planning than are one time observations.

\section{CONCLUSION}

The results support the idea that if professionals involved in early intervention programmes are to help the child in a meaningful and effective way they should be aware not only of the child's developmental status, but also of the mother's mental or emotional status and be prepared to provide help in the lacking areas.

Future studies of the findings of the effectiveness of early intervention (treated vs. non-treated) will need to pay attention to the primary caregiver's characteristics.

\section{References}

1. Barch, R. N. (1968). The parent of the Handicapped Child: A study of child-bearing practices, Springfield, Illinois, Charles $C$. Thomas.

2. Bobath, B. (1967). The very early treatment of cerebral palsy children. Dev. Med. Child. Neurol., 9: 373-390.

3. Bronfenbrenner, U. (1975). Is early intervention effective? In B. Z. Friedlander, G. M. Stemith and C. E. Kirk (eds). Exceptional Infant, Vol. 3, New York, Brunner Mazel.

4. Brophy, J. E. (1970). Mothers as teachers of their own pre-school children. The influence of socio economis status and task structure on teaching specificity. Childs Dev., 41: 79-96.

5. Broussard, E. \& Hartner, M. S. (1971). Further considerations regarding maternal perceptions of the first born. In J. Hellmuth (ed.) Exceptional infant. Vol. 2, studies in Abnormality New York, Brunner/Mazel.

6. Burden, R. L. (1980). Measuring the effects of stress on the mothers of handicapped infants: Must depression always follow? Child Care, Health \& Dev.. 6: 111-125.

7. Shearer, M. S. (1976). A home-based parent training model. In D. L. Lillie, P. L. Trohanis and K. W. Goin (eds.). Teaching Parents 1o Teach-A Guide for work with the Special Child. New York, Walker \& Co.

8. Carey, W. B. and McDevitt, S. C. (1978). Revision of the infant temperament questionnaire. Pediatrics, 61: 738-739.

9. Fullard, W.. McDevitt, S. C. and Carey, Wm B. (1979). The toddler temperament scale.

10. Greenberg, N. H. (1971). A comparison of infantmother interactional behaviour in infants with atypical behaviour and normal behaviour in infants. In The Exceprional Infant, Vol. 2. New York, Brunner/Mazel.

11. Hollingshead, A. B. (1958). Social class and Mental Illness, pp. 389 - 397 New York, John Wiley \& Sons Inc.

12. Jaeger L. (1980). Home program instruction sheets Infants and young children. University of Kentucky.

13. Klinger, E. S. (1975). Achievement and performance: $A$ role analysis. $\mathrm{Ph}$. D. Dissertation. New York University.

14. Kogan, K. L., Tyler, M. and Turner, P. (1976). The process of interpersonal adaptation between mothers and their cerebral palsied children. Develop. Med. Child Neurol., 16: 519-527.

15. Lefcourt, H. M. (1976). Locus of Control, Current Trends in Theory and Research. Lawrence Erlbaum, New York, John Wiley \& Sons.

16. Mackeith, R. (1973). The feelings and behaviour of parents of handicapped children. Develop. Med. and Child. Neurol., 14: 524-527.

17. Parke, R. D. (1977). Parent-infant interaction: Progress, paradigms and problems. In G. P. Sackett and H. C. Maywool (eds.). Application to Observational Ethological Methods of the Study of Mental Retardation. Baltimore, University Park Press.

18. Pearson, G. H. J. (193I). Some early factors in the formation of personality. Am. J. of Orthopsychiatry. 10: 284-291. 
19. Rotter, J. B. (1954). Social Learning and Clinical Psychology. Englewood Cliffs, New Jesey, Prentice-Hall.

20. Rotter, J. B. (1966). Generalized expectancies for internal vs. external control of reinforcement. Psychological Monographs 80 (Whole No. 609).

21. Schaefer, E. S. (1977). Parent interview, predictors of teacher's ratings of school adaptation: concepts, method and findings. Paper presented at the Second International Congress on Developmental Screening, Sante Fe.

22. Schaeffer, E. S. (1961). Converging conceptual models for maternal behaviour and for child behaviour. In J. E. Glidewell (ed). Parental attitudes and Child Behaviour. Springfield, Ill., Charles C. Thomas.

23. Schaefer, E. S. and Bayley, M. (1964). Correlation of maternal and child behaviours with the development of mental abilities data from the Berkeley Growth Study.
Monographs of the Society for Research in Child Development. 29: 6 No. 97.

24. Shearer, M. S. (1976). A home-based parent training model. In D. L. Lillie, P. L. Trohanis and K. W. Goin (eds.). Teaching Parents io Teach-A Guide for work with the Special Child. New York, Walker \& Co.

25. Vulpe, S. G. (1969). Home Care and Management of Mentally Retarded Child. Toronto, Ontario, National Institute on Mental Retardation.

26. Voysey, J. M. (1975). A Constant Burden. London, Routledge and Kegan Paul.

27. Wilson, J. M. (1974). Physical Therapy in infant home management programs. On C. Heriza (ed.). The Comprehensive Management of Infants at Risk for CNS Deficit. Chapel Hill, M. C., University of North Carolina. 